\title{
ANALYSIS OF SOCIAL MARKETING FOR ANTI-CORRUPTION CAMPAIGN: CASE STUDY OF FILM “KITA VERSUS KORUPSI”
}

\author{
Rosidah \\ Jurusan Marketing Communication, Faculty of Economic and Communication, BINUS University \\ Jln. Kemanggisan Ilir III No. 45, Kemanggisan-Palmerah, Jakarta Barat 11480 \\ ochid35@gmail.com
}

\begin{abstract}
The paper aims to explain the application of commercial marketing theory in a social marketing campaign. This study derives from secondary sources have been conducted, including previous researches and published articles. The writer finds yhat the theory of marketing mix has been used to study the film proposition. Furthermore, another " $P$ ", namely Partnership, and segmentation has also been added to the campaign. The marketer has applied the commercial marketing approach in the film, as one of the campaigns for anticorruption in Indonesia, to ensure that the campaign will be effectively delivered for the target audience. This finding can serve as a guideline for best practices in social marketing campaign for other sector or mission. In addition, the paper doesn't aim to evaluate the effectiveness of the film as a social marketing campaign. It just wants to analyze the application of commercial sector marketing that applied in the film.
\end{abstract}

Keywords: social marketing, film, anti-corruption campaign, non-profit organizations

\begin{abstract}
ABSTRAK
Makalah ini bertujuan untuk menjelaskan penerapan teori pemasaran komersial dalam kampanye pemasaran sosial. Penelitian ini berasal dari sumber-sumber sekunder yang telah dilakukan, termasuk penelitian sebelumnya dan artikel yang telah diterbitkan. Penulis menemukan bahwa teori bauran pemasaran telah digunakan untuk mempelajari proposisi film. Lebih lanjut, "P" yang lain, yaitu Partnership, dan segmentasi juga telah telah ditambahkan dalam kampanye. Pemasar telah menerapkan pendekatan pemasaran komersial dalam film, sebagai salah satu kampanye anti-korupsi di Indonesia, untuk memastikan bahwa kampanye akan disampaikan secara efektif untuk target pemirsa. Temuan ini dapat berfungsi sebagai pedoman bagi praktik terbaik dalam kampanye pemasaran sosial untuk sektor atau misi lain. Selain itu, penelitian ini tidak bertujuan untuk mengevaluasi efektivitas film sebagai kampanye pemasaran sosial. Artikel ini hanya ingin menganalisis penerapan pemasaran sektor komersial yang diterapkan dalam film.
\end{abstract}

Kata kunci: pemasaran sosial, film, kampanye anti-korupsi, organisasi non-profit 


\section{INTRODUCTION}

The term "social marketing” was first introduced by Kotler and Zaltman (1971) to refer to the application of commercial marketing principles in the context of socially desirable goals. Social marketing is a strategy for addressing the social issues as well as many others. According to Kotler, et.al (2002) social marketing is the use of marketing principles and techniques to influence a target audience to voluntarily accept, reject, modify, or abandon a behavior for the benefit of individuals, groups, or society as a whole. The paper tries to illustrate how the commercial marketing principles have been applied in a social marketing campaign to be more effectively delivered to the target market. For this purpose, a study on film "Kita versus Korupsi" (Us versus Corruption) has been conducted. The film is one among many social campaigns initiated by the Indonesian Corruption Erradication Commission (KPK). The theory of marketing mix (4Ps) will later be used in the analysis. It refers to how well the marketer or the agent has applied the theory of product concept, pricing strategy, communication technique (promotion) and channel distribution concept in their campaign. In addition to that, the discussion on another theories found in the campaign will be followed.

\section{Social Marketing: An Alternative Approach for Anti-Corruption Campaign}

Andreasen (2006) defined social marketing as: "the application of commercial marketing technologies to the analysis, planning, execution, and evalutation of programs designed to influence the voluntary behaviour of target audiences in order to improve their personal welfare and that of their society”.

Similarly with commercial sector marketing, that sells goods and services, social marketing tries to sell behavior change. The social marketers aims to influence the audience to change their behavior for the sake of improvement on their life, for example in terms of improving health, protecting the environment, preventing injuries, and many more.

Change agents or social marketers typically want target audiences to do one of four things: (a) accept a new behavior; (b) reject a potential behavior; (c) modify a current behavior; or (d) abandon an old behavior (Kotler et.al., 2002). Further, Kotler stated that perhaps the most challenging aspect of social marketing is that it relies on voluntary compliance rather than legal, economic, or coercive forms of influence. In many cases, social marketers cannot promise a direct benefit or immediate payback in return for a proposed behavior change. However, Donovan and Henley (2003) modified the definition social marketing to include involuntary behaviours, as there are many instances of social marketing where the individual's voluntary behaviour is constrained, for example, under threat of legal sanction (drink driving) or other regulations (smoke-free venues), or where the individual's choices are restricted (e.g. government restrictions on trans fatty acids in processed foods) (in Henley et.al, 2011).

How commercial sector marketing different with social marketing, can be found in the following table:

Table 1 Differences between commercial marketing and social marketing

\begin{tabular}{ll}
\multicolumn{1}{c}{ Commercial marketing } & \multicolumn{1}{c}{ Social marketing } \\
\hline Aims to get profit & Aims to encourage good behavior \\
Funded by investment & Funded by taxes and donations \\
Priority to private sector accountability & Priority to public sector accountability \\
Performance is measured by profit and market share & Difficult to measure performance \\
Aimed at short-term behavior & Aimed at long-term behavior \\
Avoid any controversial products or services & Often offer controversial behavior \\
Only to accessible target market & Often choose targets that are at high risk \\
Hierarchical decision-making & Participatory decision-making \\
Relationship based on competition & Relationship based on trust \\
\hline
\end{tabular}

(Setyabudi, 2009) 
Previously, Henley, et al (2011) has conducted a research in the form of case study to analyse the application of the commercial marketing principles to a social marketing campaign. The objective is to explain how the principles of marketing can be applied to the planning and implementation of a social marketing campaign. The case illustrates that identifying the right themes is very crucial in reaching the desired target audiences to create attitudinal and behavioural change. In addition to that, a coherent implementation of the marketing mix is necessary to ensure the effectiveness of the campaign over time.

Another research to analyze the importance of application of commercial marketing in a social campaign was conducted by Barlovic (2006), that found the understanding on communication strategy in advertising is very important to be applied in a social campaign for child obesity. The message needs to be very clear and not too cognitive for children to understand. It also needs to consider emotional appeal and behavioral relevant manner.

Those studies show the importance of understanding commercial marketing theories in order to ensure that the marketer can control to meet the needs of the target audience.

\section{Basic marketing concept}

Peter Drucker once said that there will always, one can assume, be need for some selling. But the aim of marketing is to make selling superfluous. The aim of marketing is to know and understand the customer so well that the product or service fits him and sells itself. Ideally, marketing should result in a customer who is ready to buy. All that should be needed then is to make the product or service available (in Kotler, et al., 2006).

In conducting a social marketing campaign, the social marketer will apply the similar marketing principles and techniques as in commercial marketing. According to Kotler et.al. (2002) the most fundamental principle underlying marketing is to apply a customer orientation to understand what target audiences currently know, believe, and do. The process begins with marketing research to understand market segments and each segment's potential needs, wants, beliefs, problems, concerns, and behaviors. Marketers then will select the target markets they can best affect and satisfy.

Marketers also should establish clear objectives and goals. They then use four major tools in the marketer's toolbox, which is the "4Ps", to influence target markets: product, price, place and promotion, also referred to as the marketing mix. They carefully select product benefits, features, prices, distribution channels, messages, and media channels.

Moreover, the product is positioned to appeal to the desires of the target market to improve their health, prevent injuries, protect the environment, or contribute to their community more effectively than the competing behavior the target market is currently practicing or considering. Once a plan is implemented, results are monitored and evaluated, and strategies are altered as needed (Kotler et.al, 2002).

In the practice, social marketers do segmentation of the customers as well. Marketers will divide the market into several groups and measure the relative potential of each segment to meet organizational and marketing objectives. A market segment consists of individuals, groups, or organizations that share one or more silimar characteristics that cause them to have relatively similar product needs. After that, marketers will select the specific target markets that they can best served or satisfied. The purpose is to enable marketer to design a marketing mix that more precisely matches the needs of customers in the selected market segment (Pride \& Ferrel, 2010).

In short, we can list down the similarities between social and commercial sector marketing. Firstly, a customer orientation is applied for both of them. The marketer knows that the offer (product, 
price, promotion, and place) will need to have appeal for the target audience. Secondly, the exchange theory is fundamental. The consumer must perceive the benefits that equal or exceed the perceived costs. Thirdly, the marketing research is used throughout the process. Only by researching and understanding the specific needs, desires, beliefs, and attitudes of target adopters can the marketer build effective strategies. Fourthly, the audiences are segmented. Strategies must be tailored to the unique wants, needs, resources, and current behaviors of differing market segments. Afer that, as the fifth, all 4Ps are being considered. A winning strategy requires integrating the 4Ps, not just relying on advertising. Finally, the results are then measured and used for improvement. Feedback is valued and seen as "fee advice" on how to do better for next time.

\section{Developing Marketing Mixes}

Marketing Mix consists of the four marketing activities, which are product, price, promotion and place (distribution). These activites are planned, organized, implemented, and controlled to meet the needs of the customers within the target market.

A marketing mix strategy limits alternatives and directs marketing activities toward achieving organizational goals. In developing the product, a nonprofit organization usually deals with ideas and services. Problems may evolve when an organization fails to define what it is providing. Distribution decisions in nonprofit organizations relate to how ideas and sercives will be made available to clients or audiences. If the product is an idea, selecting the right media to communicate the idea will facilitate distribution. Making the promotional decisions may be the first sign that a nonprofit organization is performing marketing activities. They can use advertising and publicity to communicate with clients and the public. Direct mail, personal selling, and special events are also among the techniques that nonprofit organization can use to promote. In pricing strategy, generally the decision making is more complex then applying the product and promotional techniques. A broadest definition of price (valuation) must be used to develop nonprofit marketing strategies. Financial price, an exact dollar value, may or may not be charged for a nonprofit product (Pride \& Ferrel, 2010).

\section{Corruption in Indonesia}

Poverty, low level of education, criminality, unemployment, hygiene and health issues (and many more) are among the problems that waiting to be solved by the Indonesian government. At this point, it is known that the issues are sometimes complex. The government also aware of the necessity of these problems to be solved, since the social problems have potential obstacles for the country's development.

Not to mention corruption, as one among the social issues that has became dramatically endanger the national stability. The existence of corruption practices has been found since long time ago. It is rather than decreasing, even the tendency is increasing (www.indonesiabersih.org).

According to CPI (Corruption Perception Index) 2011 that has been conducted by Transparency International, Indonesia is in the score of 3.0, slightly increase 0.2 compare to last year score 2.8. However, according to Transparency International, the achievement is not that significant since it still did not reach the target of 5.0 in CPI 2014.

The CPI result is based on the incorporation of 17 surveys conducted by international institutions in 2011. The range of the index is 0 to 10 , which shows that the smaller the value, the higher the corruption potential in the country.

Compare to some countries, Indonesia is in the 100th rank together with another 11 countries such as Argentina, Benin, Gabon, Madagaskar, Malawi, and so forth. In the meantime, for southeast asia region, Indonesia is located far below Singapore (9.2), Brunei (5.2), Malaysia (4.3) and Thailand 
(3.4). Thus, according to Natalia Subagyo (The Chief of Transparency International Indonesia), the index shows an important message that there is still no significant changes in the effort of erradication corruption in Indonesia. (www.ti.or.id)

Corruption practices, most of the time, has been seen as something "big" and "complex". Embezzlement, bribery (conducted by top management), money laundry are among practices that are popular as corruption. But, do people ever be aware that simple things can also be considered as corruption. Cheating in the class, marking-up budget or financial report, bribe lower level officers to speed up administration process, are among examples that we can find it around us, which sometimes we accept that as "normal" situation.

There have been many efforts planned and conducted to decrease the tendency of practising corruption. It starts from a persuasive approach until the legal enforcement. According to KPK, there are still lacking educational materials of anti-corruption, thus toghether with TII, they initiated a social marketing campaign through a film.

\section{The Film of Kita versus Korupsi (Us versus Corruption) : How is it done?}

The film, entitled "Kita versus Korupsi”, is formed in omnibus format which comprises of four short movies. The idea is to parse the everyday corruption practices that had already been accepted as normal action, and sometimes people are not aware that they've already participated in those practices. If along this time public are just silence, accept those practices, and only hope to few agencies to acting on corruption, then the period should end now. Everyone can take part in that action, and those who want to stop corruption, must begin with themselves.

It aims to increase public awareness and expect that the community will actively participate in fighting against corruption in any kind of forms. The film can be categorized as social marketing campaign. According to Lefebvre (2011), social marketing is the application of the principles and techniques of marketing to promote social change or improvement; such as research on public health issues, prevention of accidents (Smith, 2006), environmental issues (Maibach, 1993 ), transportation demand management(McGovern, 2005) or another social needs.

\section{The Contest: A Start of Creating the Movie}

It was started by a contest initiated by Transparency International Indonesia (TII) that aimed to get ideas for the film stories. The contest was addressed to the public, especially the youth. The best ideas will be chosen for the stories of the short movies (www.ti.or.id).

According to TII, the idea of making the short film emerged from the concerns that there is lacking on the educational materials for the campaign against corruption. The film can enrich the content of television programs, especially in rural areas. In addition to that, it also can be accessed through social media.

The contest was aimed to screen the ideas of stories, which perhaps can be inspired from personal experiences of the publics, that met the corruption phenomenon in their surroundings. The period of the contest was about one month in 2011 which juries selected the best 50 stories. Then, it was filtered to only four best stories. Audiences could also vote to which story they fond of on the website provided by the commmittee. 


\section{The Stories: An Omnibus Form}

The film emphasizes the drama of four short stories, each has 30 minutes duration, comprises of: "Rumah Perkara” (Film by Emil Heradi); "Selamat Siang Risa...!” (Ine Febrianti); "Pssst Jangan Bilang Siapa-siapa" (Chairun Nissa); and "Aku Padamu” (Lasya F. Susatyo). The nature of the film is non-commercial which describes about daily issues that we could find it in our environments. It is lightweight packed to be easily understood by the public.

"Rumah Perkara" (The Troubled House) has an overall melancholic and dramatic storyline, enhanced by its sweeping cinematography of the traditional village in which it is set. The story is about the headman (lurah), Pak Yatna, who must choose between defending the people's land or helping residents evicted in favor of a real estate project belongs to a businessman that seems have supported Pak Yatna to win the election as the headman in the village. Thus, the businessman hopes the eviction will run smoothly because of Pak Yatna's help for reciprocation. However, there is a widow's house left becomes a barrier. Evidently, Pak Yatna has an affair with the widow (Ella), thus he has difficulty to send the woman away from her house. He is also afraid of his affair being revealed. Faced with the fate of his village, his promise to the families and citizens to become a protecting leader, Pak Yatna should be able to make decisions either to support or oppose the eviction.

The second movie, "Aku Padamu” (I to You), tells the story of two lovers wanting to get married but who run into administrative obstacles, which then tempts the groom-to-be to resort to corruption to speed up the process of legitimating their married. The story tells about two lovers (Laras and his boyfriend) who attempt to get married, but then face the time constraints and administrative requirement. As her boyfriend (the prospective bridegroom) wants to bribe the officials to expedite the affairs of KUA, Kantor Urusan Agama (The office of religious affairs), Laras (the prospective bride) is refused to do it. It reminds her of Pak Markoen, her elementary school teacher, who refused to bribe her father (an officer in a government office) in order to become a permanent teacher. Because of it, Pak Markoen couldn't teach anymore in that school and had to change his job to become a clown. She really admires the Pak Markoen's life principles of living “clean”. Because of her upset to her corrupt father, makes her reluctant to ask for her father's blessing for the marriage. Then the two lovers are arguing, how could a marry in the holly presence of God is started with a bribe to God?

"Selamat Siang Risa!” (Good Afternoon Risa!) is mostly set in the struggling times of the 1970s, that shows the dedication and honesty of a warehouse guard who refuses to participate in the illegal stockpiling of rice. It is about Rissa Arwoko, a project procurement officer who is asked to pass the construction project of a mall. Surely, the payoff is definitely in sight. With her authority, she could easily give the consent. Facing a moral dilemma, Risa is remembering her father, Arwoko, who was really persistence to keep the trust eventhough the family was in a bad situation. At that time, a businessman had tried to bribe Arwoko, to be able to use the company's state-owned warehouse that was under Arwoko's guard. The father inisted to refuse the money though he was in dire need of funds for the treatment of his son who was seriously ill. Rissa is a woman whose career is on the rise. The styles and needs (for business and life) in Jakarta is not cheap. Faced with these choices, Rissa has to choose between rejecting or peace with the crime.

The last movie in the omnibus is "Pssst Jangan Bilang Siapa-siapa” (Shh, Don't Tell Anyone) shows three high school students expose the everyday corrupt practices they encounter and even participate in. It talks about the lifestyle and permissiveness to practice of extortion in a school which is then recorded by a student, named Gita. Through Olla, her classmate, Gita has the opportunity in exposing the real situation of her school. Olla is a student who always be an up-dated person with new gadgets and fashion, because most of the time Olla relies on deceiving her parents by marking-up all her request for school equipment and her pocket money. The family doesn't bother about it because both her father at the office and her mother at home are doing the same thing too. At school, Olla and 
her friends had wittingly become the principal and the teacher's victims of the trading book at school. Whoever did not buy the book from them (with the mark-up price) will lose. Through playing a fun gadget, Gita and Olla reveal a lot of issues around them.

( media release www.indonesiabersih.org)

The film becomes a form of anti-corruption campaign. Through a pop culture media that involves basic values, it advises the audience that morale of anti-corruption should start from the family. Each short film presents story that illustrates daily life situations. It also shows when, where, and how the corruption virus infects someone's life.

The genre of the four short films are drama and it is packed to be easily understood by the audiences which come from various ages and cultures. The social marketer expects that after watching the movie, audiences can see the picture of how close themselves to the origin of corruption. Also, it is expected that they can be aware of it, and in the end they can stop the corruption chains before it becomes an endemic.

\section{The Production}

The non-commercial four short films omnibus is a joint production of Transparency International Indonesia (TII), The Corruption Erradication Commission (KPK), Management Systems International, The U.S. Agency for International Development (USAID) and Cangkir Kopi. The film is not a one series of story, but comprises of four short stories which has 15-20 minutes duration each. It also has intensely involved the public. As it has been mentioned earlier that the idea of the stories were originated form a contest. Then, after the best four stories were selected, a workshop was conducted for story development (scenario). There were also several discussion forums which involved many media figures, social media activists, journalists, including the chairman of KPK, in order to explore and develop the ideas.

In the making of the film, there was also support from the community, especially the young filmmakers, directors, actors, scriptwriters and also crews. They have contributed to the prevention of corruption through a film.

\section{The Film Screening}

After the premiere of the movie, it was to be screened and discussed in at least 17 cities in Indonesia. The film screening will be conducted by TII and the proposal for asking the film screening in their institutions or organizations can be made by contacting TII.

\section{Film as a Medium for Social Campaign: The Analysis}

Sargeant (2012) mentioned that in the 19th century, exhibitions and newspaper were the only means of publicity. However, today, the media for educating public taste are not exhibitions alone. The greatest means of education is the cinema.

As it is stated previously that the primary beneficiary of the social marketing program is the individual, a group, or society as a whole. This becomes something that differentiate the social marketing program with the commercial marketing program, which the primary beneficiary is the corporate shareholder (Kotler et.al, 2002).

Film has been chosen as the medium for spreading the message, because the marketer realized that as a pop culture, film can be effective to reach as much public as targeted (www.ti.or.id). 


\section{Analysis on the Marketing Mix of the Omnibus Project}

Marketing involves developing and managing a product available in the right place and at the right price that buyers are willing to pay. It also requires communicating information that helps customers determine if the product will satisfy their needs (Kotler, 2012).

The marketing mix refers to the concept of four marketing activities - product, distribution, promotion and pricing - that a firm can control to meet the needs of customers within its target markets. These activities are planned, organized, implemented, and controlled to meet the needs of customers within the target market.

\section{Product}

A product could be a good, service, or an idea. The main task deals with researching customers' needs and wants and designing a product that satisfies them (Kotler, 2012). In social marketing, product is the idea. In social marketing, the products are primarily ideas. In this context, the idea is "honesty and other characteristics start from home". The idea is then packed into a medium, called Film. The message that the film tries to deliver is that the combat against corruption should be started from ourselves (every ordinary people in Indonesia), then it will be continued to learning spaces such as classroom and other spaces or settings in daily life, such as workplaces, worship places, etcetera.

All stories in the film show how close we are with the corruption practices, that most of the time we thought it as a "big” and "complex" concept. In fact, it can be just simple practices By seeing the movie, it is expected that the audiences would aware of any simple things that probably have been accepted as a "normal" condition.

In the movie of "Rumah Perkara", it shows the dilemmatic situation faced by Pak Yatna. He observed that the people who suppose to be protected have to move because of the ambition of a businessman to build real estate project on the people's land. Pak Yatna is facing a condition where people don't know where to move, the land that used to be a playground for children will soon be vanished, even his own son doesn't have anymore playmate because all of his friends have moved. Pak Yatna represents many publicfigures who have promised many good things if he or she is elected. However, in the end, after being elected, all the promises have only turned as a lip service. They will still be prioritizing individuals or groups that have supported fund for them during the campaign.

When Laras was kid, she saw her father was checking and looking for "an envelope” (indeed with some money inside) from every application document. When her father came to a document file, he kept checking but no envelope was there. Laras then found out it was the document of Pak Markoen, her teacher whom she admired. This is the story that we can see in the movie of "Aku Padamu". Laras and her friends at school found Pak Markoen as a great teacher. However, since Pak Markoen didn't want to bribe the officer, which was Laras' father, in his application to become a permanent teacher, he was then rejected. Laras knew that her father has committed many times in the corruption practices by proceeding those who paid a tribute to him, and reject those who could not provide it. Seeing this fact, Laras then becomes a woman who determined to live without corruption. And she showed that when her boyfriend wanted to bribe the KUA's officer (Office of Religious Affairs - for married purpose).

"Selamat Siang Rissa!" shows an obvious story that in the end Rissa rejects the money because she is inspired a lot by the figure of her father, Arwoko, a warehouse employee who paid little but tried to resist from bribes filed by a rice hoarder who wanted to rent the warehouse. He was really persistence in keeping his principles of never make a peace with corruption. In the movie, we can see that though his family really needed money for bringing the son to hospital and buying rice that has been finished, but he rejected the money since he knew that once he received the money, then he has 
sacrified the nobel principles that he kept along this time. Rissa has learned this value of life from his father.

In the the story of "Pssst...Jangan Bilang Siapa-siapa", instead of buying the textbook from the teacher, Gita prefers more to buy the textbook form a bookstore, because it is cheaper than the book the teacher sells, since it has been mark up. However, almost all her friends bought the book from the teacher. And as the result all students will get good marks, except the students who bought it elsewhere, such as Gita. The audiences are suggested not to participate in the form of corruption by buying book from the teacher only to get good mark. It shows that if you buy it only because you expect something in return such as good mark, you have already conducted bribery.Why Gita could have such a nobel principles, while her friends seem forget about it? The film shows that Gita got the value from her family. Her family (read: parents) teach her that in order to get something she wants, she should show some effort.

\section{Place (Distribution)}

A product should be available at the right time and in convenient locations (Kotler, 2012). Henley et.al (2011) added that place in marketing involves two main considerations, besides to think how to make the product conveniently available, the marketers also need to think about how to manage any intermediaries. Helplines and websites are used extensively in social marketing to provide a convenient "place" where the product or idea can be made more available to the consumer. Where social marketers are recommending tangible products or services, the same principles of access apply.

Currently, the film is yet screened through the main cineplex in Indonesia, such as 21 or BlitzMegaplex group. The screening of the film will depend on request from any individual, organizations, group or agency. Those requests have to meet the requirements set by TII, as the film screening organizer. Taken into account the requirements, it shows how marketers handle the intermediaries (any individuals, groups, or instituions that request the film to be screened in their places) in this social campaign. For example: the number of viewers in a particular place should be minimum 50 viewers. This is to assure that the intermediaries have some potential viewers for their "product". Besides that, the film screening can not be stand alone. It should be designed together with workshops, seminars, discussions, pers conference, festivals, community event and teaching materials. This requirement is to make sure that intermediaries will "sell" the idea with the right packaging. Thus, the idea can be delivered very well to the audiences. Another particular reguirement is the marketer will recommend the intermediaries to provide special equipment, to ensure the quality of film screening. Therefore, the idea (film) will be played with the right tools that can enhance the attractiveness of it. In addition to that, the film screening must be free of charge, since the purpose is for non-commercial campaign. Thus, audiences do not need to pay for the ticket to enter the cinema. Intermediaries should "sell the product" with the "price" regulated by the marketer. No mark up is allowed. Lastly, the intermediaries also are not allowed to copy the materials. It is strictly prohibited to protect the rights of the "product".

(www.indonesiabersih.org)

TII as the marketer, also has conducted some roadshows for film screening to some big cities in Indonesia, namely Jakarta, Makassar, Semarang, Malang, West Java and many more. It has also been screened in campuses, schools, private cinemas, institutions, and governemnt offices.

\section{Promotion (Communication)}

It is the activities used to inform individuals or groups about the organization and its products. It aims to increase public awareness of the organization and of new or existing products (Kotler, 2012). Henley et.al (2011) stated that decisions relating to a promotion strategy should be based on 
three criteria: (1) The purpose of the communication; (2) The target audience's preferences; and (3) The attached costs (Thackery et al, 2007)

Promotional tools include advertising, personal selling, sales promotion and public relations (Pickton and Broderick, 2005 - in Henley et.al, 2011).

The film was communicated through several means. Public relations, as one of the promotional mix strategy used, has successfully received an enormous publicity. Many news coverage or featured articles can be found in mass media, starting from printed media, broadcast media, as well as online media. The social marketer also set up an official website for the film, www.indonesiabersih.org. The website becomes the source of related information for those who interested and needed it.

The focus of the promotion is to young people; thus, the marketer also utilizes the online social media for communicating the film to them. Facebook, Twitter, YouTube, and Flickr, are among the online social media used for this purpose.

Personal selling approach is also used to communicate with the target audience. After the film screening, the marketer will conduct discussion with the audiences. Here, they need to give a good presentation to them. The presentation should attract the audience's attention, can stimulate their interest and also sparks a desire for the "product" (in this case is idea) of anti-corruption. The marketer must listen to audience's questions, comments, feedback, and observe their responses.

\section{Price}

It relates to decisions and actions associated with establishing pricing objectives and policies and determining product prices (Kotler, 2012). Price is the cost of the product, both monetary and non-monetary. Price includes the concept of 'exchange' where the buyer gives up something in return for the product (Henley et.al, 2011). Price relates to the cost, which is not necessarily always in term of money, but can also be relate to time, effort, physical discomfort, and possibly guilt.

The film tries to persuade the audiences to support anti-corruption campaign. Thus, they are asked to be aware of any kind of corruption forms in their surroundings. The marketer also persuades the audiences to avoid and to not participate in that actions. If the audiences are then aware and don't want to participate in a particular type of corruption, there will be consequences (whether they are aware or not). The consequences, most of the time, can be any inconvinient situation or condition.

For example, in the case of Gita (Pssst...Jangan Bilang Siapa-siapa!), she has to take the consequence of not getting a good mark in the subject the teacher taught. It is because she didn't buy the book from the teacher. This is the cost that Gita should bare because of keeping her principles for being honest; but luckily the film shows how peaceful Gita is by realizing that she is not participated in the corruption practices.

In "Aku Padamu”, Laras is willing to get her marriage delayed, because she does not want her boyfriend to bribe the officer. This is the cost that she needs to pay since she doesn't want to pollute the sacred intention with corruption. Moreover, she doesn't want to bribe God. In the end, the two lovers show how happy they are knowing they are able to avoid a wrong way to reach something sacred. In another case, Arwoko (Rissa's father in “Selamat Siang Rissa!”) is compliant with his poor living condition, doesn't have property and money to buy food and medicine for his son, whereas the opportunity for lots of money was in front of his eyes. Thus, this is something that should be borne by Arwoko because he wants to keep her life principle. "I might be stupid, might be wrong too, but I will not regret this stupidity and mistakes until I die” said Arwoko. Luckily, the next day the son get well. Perhaps this is a bless from God because of his commitment?!? Everyone has their own interpretation. 
And how about Pak Yatna? Probably, this is the only story that shows how one would upset when he has done a lot of cheatings. He receives less respect from the villagers because he can not protect them from the businessman's ambition. He also has to face the reality of losing his son because of the fire. Not to mention the turmoil that plagued in himself, now it becomes obvious the loss if he didn’t buy the idea, the risk if he didn’t want to spend some cost of “buying the idea”.

\section{Another findings}

\section{Segmentation}

Seeing from its target audience, the marketer was using the undifferentiated marketing strategy (mass marketing). It is a strategy in which an organization defines an entire market for a particular product as its target market (Kotler, 2012). It can be seen from the single marketing mix (4Ps) strategy that has been done, and there is no segmentation for marketing this product. Perhaps it is because the marketer wants to increase a massive awareness from the public of how close they are to the corruption practices in the daily life. They want to reach as many people as possible, thus it focuses on a basic customer need rather than on differences among them. The movie also shows simple stories, lightweight and easy to understand by the public.

Besides that, the omnibus shows various background of people, such as government agency, housewife, manager of a private company, principal, teacher, students or teenager, young adult, and many more. It shows how the film wants to reach many layers of people. Not to mention also time; that corruption has already existed since long time ago (we can see from the film of "Selamat Siang Rissa!” that viewing the year of 1970s).

\section{Partnerships}

As mentioned by Henley et.al, 2001, in addition to the "4Ps", the fifth "P" for Partnerships needs to be added when creating and implementing social marketing campaigns, as societal problems needs be addressed through a concerted effort of many parties and stakeholders. And so does the corruption, which in combating it, all level of publics need to be aware and take responsibility to participate against it in one way or another. Thus, the process of making the film has involved a lot the participation of public. Starting from the idea of the story, workshops or seminar for developing the story, until the distribution of the film have done by building relationship with the public, such as young movie-makers, directors, actors, scriptwriters, crew, as well as any individuals or groups or organization that wish to play the movie in their places. TII, as the initiator, also needed to find some partners for joining forces. Thus, it collaborated with KPK, USAID, Management System International and Cangkir Kopi.

\section{Messages and its impacts}

All stories in the short movies show that corruption practices are also something that are simple. We can find it easily around us which some times we just accept it as something "usual". By seeing the movie, it is expected that the audiences will aware of it, and start to fight those simple corruption practices from themselves. There is no character in all stories complaining and reporting those practices, that hurted many people and done by their close-personal person, to the authorities. Perhaps the film doesn't want to give a focus on it, but only the audiences are asked not to participate in it. By doing so, the audiences already show their determination for not accepting any corruption practices. So, start from yourself.

In the movie, though somehow it shows benefit of "buying the idea" yet in a less degree, it shows more on the losses that the persons should bare because of saying no to corruption. Gita has to accept that her grade is not good, because she didn't buy the book from her teacher. When the widow 
doesn't want to move, she often is terrorized, even the house is burned. The teacher (Pak Markoen) even was dismissed because he refused to bribe. Therefore, what are the benefits of being clean? If we see in the social marketing theory, to influence people to change their behavior, the marketer needs to show and more highlight what will be the goodness when they are agree and follow your message. In another way, perhaps the film can show what is the adverse impact when they participated in the corruption practices. About this issue, Kotler already mentioned that the most challenging aspect in social campaign is on the voluntary compliance rather than legal, economic or coervice forms of influence. However, Henley et al (2011) added that in social campaign the marketer can also include involuntary behavior, since it is found that people's voluntary behavior sometimes is constrained. Thus, the film can also show the legal sanction or other regulations, or where the individual's choice are restricted . By doing so, the audiences are showed a balance impact of every situation related to corruption practices.

Every person who sees the movie has to analyse it by themselves. Fortunately, to answer about this, the marketer requires discussions, workshops, seminars, etc that has to accompany the film screenings. At least there are some spaces to talk more about this issue.

\section{CONCLUSION}

Through the film of "Kita versus Korupsi”, a social marketing campaign has been conducted as an effort to address social issues. According to some previous researches, it is found that the application of commercial sector marketing in social campaign can ensure the effectiveness of the campaign delivery to its audience. The marketer can also take more control to ensure that they will meet the needs of the audiences. From what has been analysed, it is found that TII as the marketer has successfully apply the theory of commercial sector marketing in the film. The marketer has implemented the marketing mix theory in their product concept, price setting, communication technique and the distribution channel strategy. Additionally, the 5th "P", namely Partnership, and segmentation has also been applied in conducting the campaign. Yet there are still some points for improvement that can be added to ensure the effectiveness of the program. By showing the benefits of "buying the idea" perhaps it can persuade the audience to follow it. However, the marketer should also show the adverse impacts for "not buying the idea" or for participating corruption practices. Some legal or economic threats, or coercive forms of actions can have some portion in the movie. It will then anticipate the constrained of people's voluntary behavior. The social marketing campaign on fighting against corruption also should not stop only at this stage. The campaign should be sustained over time to ensure that the target behavior will be adapated by audiences. Moreover, the support of government or authority level will also be needed to strengthen the power against corruption. In general, to ensure that the message of the social marketing campaign to be received by the target audience, it is strongly recommended for marketer to adopt or implement the commercial sector marketing for their campaign. Specifically in this case, the understanding and application of marketing mix (4Ps) in the social campaign. By doing so, the marketer can meticoulously plann and execute the activity to the audience. 


\section{REFERENCES}

Barlovic, Ingo. (2006). Obesity, Advertising to Kids, and Social Marketing. Young Consumers, Quarter 3, Emerald Group Publishing Limited, pp. 26 - 34.

Henley, N., Raffin, S., \& Caemmerer, B. (2011). The Application of Marketing Principles to a Social Marketing Campaign. Marketing Intelligence \& Planning, Vol. 29 No. 7, pp. 697 - 705.

Indrasafitri, $\quad$ D. $\quad$ (2012). $\quad$ KPK $\quad$ screens $\quad$ antigraft $\quad$ films http://www.thejakartapost.com/news/2012/01/28/kpk-screens-antigraft-films.html accessed on $2 / 2 / 2012$

Kotler, P, et.al, (2006). Marketing Management: An Asian Perspective (4th Edition). Pearson Education South Asia Pte Ltd: Singapore.

Kotler, P., Roberto, N., \& Lee, N. (2002). Social Marketing: Improving the Quality of Life (2nd Edition). Sage Publication, Inc. : California.

Official website of Transparency International Indonesia (TII) www.ti.or.id

Official website of Film “Kita versus Korupsi” www.indonesiabersih.org

Pride, W. M. \& Ferrel, O.C. (2010). Marketing (15th Edition). South-Western, Cengage Learning: Canada.

Percy, L. (2008). Strategic Integrated Marketing Communication: Theory and Practice. Elsevier Inc.: UK.

Sargeant, A. (2012). GPO Films: American and European Models of Advertising in the Projection of Nation. Twentieth Century British History, Vol. 23 No. 1, pp. 38-56

Setyabudi, D. (2009). Social Marketing sebagai Alat Perubahan Sosial http://djokosetyabudi.blogspot.com/2009/03/social-marketing-sebagai-alatperubahan_853.html Accessed on 2/2/2012

Transparency International Indonesia. (2011). Indonesia Peringkat ke-100 Indeks Persepsi Korupsi 2011. http://www.ti.or.id/index.php/news/2011/12/02/indonesia-peringkat-ke-100-indekspersepsi-korupsi-2011 accessed on 26/2/2012. 